\title{
GENERATIONAL DIFFERENCES IN ORGANIZATIONAL JUSTICE PERCEPTIONS: AN EXPLORATORY INVESTIGATION ACROSS THREE GENERATIONAL COHORTS
}

\author{
Ophillia LEDIMO
}

\author{
University of South Africa, Department of Industrial and Organisational Psychology, South Africa \\ e-mail: manetom@unisa.ac.za
}

\begin{abstract}
Despite several reviews of generational differences across cohorts regarding their career stages in organizations, relatively few empirical investigations have been conducted to understand cohorts' perceptions. Hence, there is paucity of studies that explored differences on the construct organizational justice across generational cohorts. The objective of this study was to explore the differences across three generational cohorts (Millennials, Generation X, and Baby Boomers) on dimensions of the organizational justice measurement instrument (OJMI). Data was collected through the administration of OJMI to a random sample size of organizational employees $(n=289)$. Descriptive statistics and analysis of variance were conducted to interpret the data. These findings provide evidence that differences do exist across cohorts on dimensions of organizational justice. In terms of contributions and practical implications, insight gained from the findings may be used in proposing organizational development interventions to manage multigenerational employees as well as to conduct future research.
\end{abstract}

Keywords: organizational justice, public service, injustice, generational cohorts.

\section{$1 \quad$ Introduction}

Research on organizational justice proposes that justice has an impact on performance-related factors in organizations. Literature indicates that organizational justice perceptions lead to employee commitment and trust [3]. It is also argued that justice improves employees' job performance in an organization [6]. This improved performance occurs because employees who perceive just and fair practices in their organization are inclined to want to perform better as a form of reciprocity [10]. Organizational justice affects what employees believe about the organization as a whole because when the internal processes are perceived as just, employees are inclined to show greater loyalty and are more willingness to behave in the organization's best interests [5, 6]. Just treatments of employees also lead to organizational citizenship behaviors that "spill over" to customers [2]. In other words, organizational justice has a positive impact on employees' organizational citizenship behavior, loyalty, and customer satisfaction.

Generational cohorts reportedly hold different perceptions of each other; these perceptions can result in conflict and misunderstandings in the workplace.
Generational cohorts in the workforce, such as Millennials, Generation X, and Baby Boomers, differ from each other in ways that are important for managers [18]. The reason that the generational cohorts differ from another in ways that matter to managers is because the differences between generations are theorized to derive from major influences in the environment within which early human socialization occurs. These influences have an impact on the development of personality, values, beliefs, and expectations that, once formed, are stable into adulthood [18]. In South Africa, there is paucity of studies investigating organizational justice, in relation to organizational justice differences across generational cohorts. Studies locally on organizational justice focused only on its relationship with employment equity [8], disciplinary procedures [31], and organizational attractiveness [23].

Hence, there is limited research that could be found regarding organizational justice and generational cohorts within the context of the South African public service. This study seeks to explore the differences across three generational cohorts (Millennials, Generation X, and Baby Boomers) on dimensions of the organizational justice construct in a South 
African public service organization, namely, government department.

\section{Literature review}

The following literature review firstly focuses on the definition of organizational justice and its dimensions. In addition, the different types of generational cohorts that are found in the workplace are identified and discussed.

\subsection{The construct organizational justice}

The construct organizational justice was introduced to describe an employee's perception of their organization's behaviors, decisions, and actions and how these influence the employees' own attitudes and behaviors at work [12]. In other words, organizational justice is a personal evaluation of the ethical behavior of all organization's members [31]. This definition of organizational justice is a descriptive approach that seeks to understand why employees view certain events as just and fair as well as the consequences that follow from these evaluations $[5,6]$. Hence, justice within the organization is viewed as a subjective and descriptive concept because it captures what the individual employees believe to be right, rather than an objective reality or a prescriptive moral code.

In contrast to the positive influence of organizational justice on employee's attitudes and behavior, an injustice within an organization is perceived as a corrosive solvent that can dissolve bonds within the organization; hence, unfair practices within the organization are hurtful to employees and harmful to the organization itself $[5,6]$. It is argued that the results of unfair treatment by employees may include emotions of anger and resentment, lower production quantity and quality, greater absenteeism, greater turnover, less initiative, lower morale, lack of cooperation, spread of dissatisfaction to coworkers, fewer suggestions, and less self-confidence [31]. It is, therefore, essential that organizations are able to identify and address factors within the organization that are likely to engender their employees' positive perception of organizational justice.

\subsection{Dimensions of organizational justice}

There are four types or dimensions of organizational justice, namely, procedural justice, distributive justice, interpersonal justice, and informational justice [3].

Distributive justice is the first fairness construct studied that focuses on the perceptions of fairness in the distribution and allocation of outcomes [23]. It focuses on the organizational reality that not all employees are treated alike and that the allocation of outcomes is differentiated in the organization [5, 6]. Second, procedural justice refers to the means by which outcomes are allocated but not specifically to the outcomes $[5,6]$. It relates to the fairness of the formal procedures required by the organization and its policy on the method of decision-making [21, 3]. Third, interactional justice refers to the perceived fairness of the interpersonal treatment used within the organization to determine outcomes [3]. It focuses on the sensitivity, politeness, and respect employees receive from their superiors during procedures. This serves primarily to alter reactions to outcomes, because sensitivity can make people feel better even if the outcome is unfavorable [23]. Lastly, informational justice is described as to whether one is truthful and provides adequate justifications for their actions and decisions in the organization $[5,6]$. It refers to the explanation, justification, or information provided by decision-makers as to why outcomes were distributed in a certain way [23, 22]. This type of justice requires that the information should be comprehensive, reasonable, truthful, timely, and candid in nature.

In addition to the four dimensions, there are five dimensions that explain organizational justice, namely, ethical leadership and management, strategic direction justice, service delivery innovation, customer relations, and diversity management justice [1, 4]. Organizational justice is a positive perception of the ethical and moral standing of the organization's leadership and managerial conduct or practices $[5,6]$. Ethical leadership and management as an aspect of justice implies that the leader and manager possess and promote justice values in the organization such as honesty, integrity, openness, compassion, humanity, equality, trust, recognition, and empowerment [4, 33]. 
Creating a justice-oriented strategic direction for the organization is one of the ways in which the organization is able to indicate its concern for the fair development and ethical execution of its purpose. Fair development of the strategic direction focuses on consultation with the relevant stakeholders during the decision-making process, which includes employees, managers, clients, customers, and labor organization [6, 4]. Service delivery and innovation as a dimension of justice highlights the responsibility of employers and employees in ensuring that they create a just and fair image of the organization with regard to the development and delivery of services or products [4]. Regardless of how the service organization defines their service and how customers or clients perceive the service, a delivered service should function seamlessly in order for customers to perceive it correctly (fair and just) [11]. Customer relation justice is basically concerned with maintaining positive relationships with customers, increasing customer loyalty, and expanding customer lifetime value $[4,16]$. Therefore, customer relations practices in the organization that are fair and just can help organizations manage customer interactions more effectively. An organization that is devoted to diversity management justice is able to give the impression that the organization has established systems that fairly evaluate, promote, and compensate its employees based on performance and ability rather than on criteria such as gender, race, nationality, or age $[19,22]$.

The above nine dimensions of organizational justice are essential in understanding and measuring the construct in this study.

\subsection{Generational cohorts}

Today's workforce presents unique leadership challenges as employees, managers, and leaders in public service organizations are from different generations representing unique attitudes, beliefs, work habits, and experiences, as they work together on operational teams. Although the different generations in the workforce can present leadership challenges, the diversity of the different age groups can also add richness and strength to the organization if all employees are valued for their contributions. The construct generational cohort refers to an "identifiable group that shares birth years, age location, and significant life events at critical developmental stages" [17, p. 66]. Generational cohorts are defined as groups of people who share birth years, history, and a collective personality as a result of their defining experiences [22, 34].

Literature indicates that within the work context, there are three generational cohorts that have been identified, which are Baby Boomers, Generation Xers, and Millennials [20, 27, and 30].

Baby Boomers as the first generational cohort; they were born between 1946 and 1964. In terms of their childhood development, they were raised in the economic prosperity of the post-World War II, and lived through the most dramatic changes in history. Baby Boomers in an organizational context are considered to be loyal, committed, goal oriented, and driven by rewards, and they value work more than the younger generations because they see work as being more central to their lives [27]. They are described as the most egocentric generation; they have spent their lives rewriting the rules [34].

Generation Xers are the second generational cohort who were born between 1965 and 1980. In an organizational context, they are currently dominant in the workforce as Baby Boomers are approaching retirement phase in their career. Generation Xers differ from the first generational cohort, because in organizations, they are considered to be independent and individualistic, placing more value on work-life balance, increased pay, material possessions, and their own careers over being loyal to their organizations [30]. This generational cohort has the privilege that technology underwent major advances during their formative years and has become an important part of their lives [15].

Millennials or Generation $Y$ are the third generational cohort who were born between 1981 and 1999 . They are the youngest generation cohort replacing Baby Boomers in the workplace with shared experienced on technological advancements and the knowledge economy. Millennials in an organizational context are described as valuing freedom, high expectation on promotions and pay increases, virtual work environment, and meaningful and fulfilling work [13]. Their advanced exposure to technology 
makes them to be a global generation, and they are able to accept multiculturalism as a way of life [25].

It is critical for managers and leaders in organization to understand each generational cohort and accommodate generational differences in attitudes, values, and behaviors. This insight will help them to capitalize on generational differences; these differences can be used to address perceptions of organizational injustices and to enhance the performance of the entire organizational workforce. It is important that every employee is held to the same work expectations, organizational policies, and procedures; yet managers and leaders in public service organizations should also consider individual employee's needs and generational differences. Organizational practices that are able to accommodate generational perceptions and address negative perceptions on organizational justice will help to promote an environment of high performance, integrity, and employee retention. It is against this background that it is hypothesized that: there are significant differences between the generational cohorts regarding their organizational justice perceptions in a public service organization.

\section{$3 \quad$ Research design and methodology}

In order to achieve the purpose of this study, a crosssectional survey was used, which refers to a design that collects data at one point in time from one sample representing the larger population [32]. The design of this study was a quantitative research. The following discussions outline the participants and sampling strategy and measuring instruments of this study.

\subsection{Participants and sampling strategy}

Sample population of this study comprised of permanent employees of a public service organization. The study adopted a random sampling technique to determine the sample size $[29,32]$. The participants were requested to complete the questionnaire, resulting in a final sample size of 289 respondents.

Table 1. Generational cohorts of the sample $(n=289)$

\begin{tabular}{|l|c|c|}
\hline \multicolumn{1}{|c|}{ Parameter } & Frequency & Percentage (\%) \\
\hline Generational cohorts / Age group & 115 & 39.8 \\
\hline Millennials born between 1978 and 2000 & 110 & 38.1 \\
\hline Generation Xers born between 1965 and 1977 & 64 & 22.1 \\
\hline Baby Boomers born between 1946 and 1964 & 64 & \\
\hline
\end{tabular}

In terms of Table 1, the sample of this study comprised of three generational cohorts. The participants included 22.1\% $(\mathrm{n}=64)$ of Baby Boomers who are born between 1946 and 1964, 38.1\% $(\mathrm{n}=110)$ of Generation Xers who are born between 1965 and 1977 , and $39.8 \%(\mathrm{n}=115)$ of Millennials who are born between 1978 and 2000 .

The sample results that are presented in Table 2 indicate that the sample size was skewed toward females were $59.5 \%(n=172)$ and males $40.5 \%(n=117)$. In terms of the different race groups represented by the participants, $78.9 \%(\mathrm{n}=228)$ were African; $9.7 \%$ $(\mathrm{n}=28)$ were white; $8 \%(\mathrm{n}=23)$ were colored, and $3.5 \%(n=10)$ were Indian. Table 2 also reflects the participants' current position composition which indicates that $17 \%(\mathrm{n}=49)$ are in management positions, $46.3 \%(\mathrm{n}=134)$ occupied professional and specialist position, and $36.7 \%(\mathrm{n}=106)$ are employed as general workers. The majority of the participants at $56.8 \%(n=164)$ have between 1 and 5 years of service with the organization. 
Table 2. Sample demographic profile $(n=289)$

\begin{tabular}{|c|c|c|}
\hline Parameter & Frequency & Percentage (\%) \\
\hline \multicolumn{3}{|l|}{ Gender } \\
\hline Male & 117 & 40.5 \\
\hline Female & 172 & 59.5 \\
\hline \multicolumn{3}{|l|}{ Race } \\
\hline African & 228 & 78.9 \\
\hline Colored & 23 & 8.0 \\
\hline Indian & 10 & 3.5 \\
\hline White & 28 & 9.7 \\
\hline \multicolumn{3}{|l|}{ Years of service } \\
\hline $1-5$ years & 164 & 56.8 \\
\hline $6-10$ years & 63 & 21.8 \\
\hline $11-15$ years & 41 & 14.2 \\
\hline Over 16 years & 21 & 7.2 \\
\hline \multicolumn{3}{|l|}{ Current position } \\
\hline Management & 49 & 17 \\
\hline Professional and specialist & 134 & 46.3 \\
\hline General workers & 106 & 36.7 \\
\hline
\end{tabular}

\subsection{Measuring instrument}

The questionnaire consisted of two sections. Section A measured the participants' biographical details which included race, age group, gender, years of service, and current position.

Section B consisted of the measuring instruments, Organizational Justice Measurement Instrument (OJMI).

The OJMI is virtually a self-administering survey and consists of 59 statements measuring the nine dimensions of justice, namely, strategic direction, distributive, procedural, interactional, informational, service delivery innovation, customer relations, diversity management, and ethical leadership and management. The statements of the questionnaire were configured using the five-point Likert scales ranging from 1 as strongly disagree to 5 as strongly agree. In the present study, the reliabilities of the dimensions were used to assess the construct validity, and it was measured using the Cronbach's alpha coefficient. The Cronbach's alpha coefficients for the nine organizational justice dimensions are presented in Table 3. The results of the coefficients are considered to be satisfactory because they were significantly greater than the recommended 0.70 [29]. They vary from 0.94 (distributive), 0.94 (ethical leadership and management), 0.90 (service delivery innovation), 0.884 (strategic direction), 0.86 (interactional), 0.88 (informational), 0.86 (procedural), 0.81 (diversity management), and 0.79 (customer relations). Overall, the reliability coefficient of the OJMI is 0.95 . 
Table 3. Number of items and reliabilities for the OJMI

\begin{tabular}{|l|c|c|}
\hline \multicolumn{1}{|c|}{ Dimensions } & Number of items & Reliability \\
\hline Organizational justice dimensions (OJMI) & & \\
\hline Distributive justice & 12 & 0.94 \\
\hline Ethical leadership and management & 11 & 0.94 \\
\hline Service delivery innovation & 6 & 0.90 \\
\hline Strategic direction justice & 5 & 0.88 \\
\hline Interactional justice & 5 & 0.86 \\
\hline Informational Justice & 7 & 0.88 \\
\hline Procedural justice & 5 & 0.86 \\
\hline Diversity management justice & 4 & 0.81 \\
\hline Customer relations justice & 4 & 0.79 \\
\hline Overall & $\mathbf{5 9}$ & $\mathbf{0 . 9 5}$ \\
\hline
\end{tabular}

\subsection{Research procedure}

Data in this study was collected using a crosssectional quantitative survey research design. This type of survey is relevant because it allows for the collection of data from respondents about their perception [29, 32]. Ethics Committees of the public service organization and research institution granted the researcher the ethical clearance to conduct the study in the organization. All employees in the organization were invited to participate voluntarily in the study through an electronic invite. The process of questionnaire completion, which included a covering letter, was facilitated by the researcher through a group administration session. Covering letter outlined the purpose of the study, and it also described the ethical conduct principles of the research process such as anonymity, confidentiality, feedback, and freedom of choice to participate in the study. The researcher collected completed questionnaires immediately after the sessions, and the questionnaires were kept in a secure place before being captured, coded, and analyzed.

\subsection{Statistical analyses}

To analyze the data of the empirical study, the Statistical Package for Social Science (SPSS version 20) was used [22]. Descriptive statistics (means and standard deviations) and Cronbach's alpha coeffi- cients were conducted in order to determine the internal consistency reliability of the measuring instrument of this study, namely, OJMI. In terms of inferential statistics, the correlational analysis and analysis of variance (ANOVA) were conducted to determine the differences between the three generational cohorts on organizational justice perceptions.

\section{$4 \quad$ Results}

The means and standard deviations as the descriptive statistics were also conducted for the variables of organizational justice and generational cohorts, in addition to the Cronbach alpha results presented above in Table 3.

Table 4 presents the mean scores and standard deviations of the organizational justice measuring instrument used in this study. In terms of the organizational justice dimensions, the sample of the participants reflected positive organizational justice perceptions, and the three generational cohorts obtained the mean scores of above 3.00. Millennials obtained the highest mean scores on all the dimensions and their overall OJMI mean score $(\mathrm{m}=3.71)$, followed by the Baby Boomers $(\mathrm{m}=3.45)$, and Generation Xers have the lowest overall OJMI mean $(\mathrm{m}=3.40)$. 
Table 4. Generational cohorts' means and standard deviations for organizational justice dimensions

\begin{tabular}{|c|c|c|c|c|}
\hline $\begin{array}{c}\text { Organizational Justice } \\
\text { Dimensions }\end{array}$ & Generational Cohorts & Mean & Sample (n) & $\begin{array}{l}\text { Standard } \\
\text { Deviation }\end{array}$ \\
\hline \multirow[t]{3}{*}{ Distributive Justice } & Millennials (1978 and 2000) & 3.51 & 115 & 0.89 \\
\hline & Generation Xers (1965 and 1977) & 3.23 & 110 & 1.05 \\
\hline & Baby Boomers (1946 and 1964) & 3.10 & 64 & 0.94 \\
\hline \multirow{3}{*}{$\begin{array}{l}\text { Ethical leadership } \\
\text { and management }\end{array}$} & Millennials (1978 and 2000) & 3.58 & 115 & 0.84 \\
\hline & Generation Xers (1965 and 1977) & 3.26 & 110 & 0.99 \\
\hline & Baby Boomers (1946 and 1964) & 3.28 & 64 & 0.92 \\
\hline \multirow{3}{*}{$\begin{array}{l}\text { Service delivery } \\
\text { and innovation }\end{array}$} & Millennials (1978 and 2000) & 3.78 & 115 & 0.93 \\
\hline & Generation Xers (1965 and 1977) & 3.39 & 110 & 1.04 \\
\hline & Baby Boomers (1946 and 1964) & 3.53 & 64 & 0.97 \\
\hline \multirow{3}{*}{$\begin{array}{l}\text { Strategic } \\
\text { direction justice }\end{array}$} & Millennials (1978 and 2000) & 3.76 & 115 & 0.79 \\
\hline & Generation Xers (1965 and 1977) & 3.45 & 110 & 1.01 \\
\hline & Baby Boomers (1946 and 1964) & 3.63 & 64 & 0.98 \\
\hline \multirow[t]{3}{*}{ Interactional justice } & Millennials (1978 and 2000) & 3.95 & 115 & 0.69 \\
\hline & Generation Xers (1965 and 1977) & 3.68 & 110 & 0.98 \\
\hline & Baby Boomers (1946 and 1964) & 3.86 & 64 & 0.89 \\
\hline \multirow[t]{3}{*}{ Informational justice } & Millennials (1978 and 2000) & 3.89 & 115 & 0.71 \\
\hline & Generation Xers (1965 and 1977) & 3.59 & 110 & 0.94 \\
\hline & Baby Boomers (1946 and 1964) & 3.60 & 64 & 0.81 \\
\hline \multirow[t]{3}{*}{ Procedural justice } & Millennials (1978 and 2000) & 3.68 & 115 & 0.80 \\
\hline & Generation Xers (1965 and 1977) & 3.19 & 110 & 0.99 \\
\hline & Baby Boomers (1946 and 1964) & 3.30 & 64 & 0.91 \\
\hline \multirow[t]{3}{*}{ Diversity justice } & Millennials (1978 and 2000) & 3.65 & 115 & 0.79 \\
\hline & Generation Xers (1965 and 1977) & 3.41 & 110 & 1.09 \\
\hline & Baby Boomers (1946 and 1964) & 3.57 & 64 & 0.92 \\
\hline \multirow[t]{3}{*}{ Customer relations justice } & Millennials (1978 and 2000) & 3.82 & 115 & 0.78 \\
\hline & Generation Xers (1965 and 1977) & 3.66 & 110 & 0.84 \\
\hline & Baby Boomers (1946 and 1964) & 3.71 & 64 & 0.86 \\
\hline \multirow[t]{4}{*}{ OJMI } & Millennials (1978 and 2000) & 3.71 & 115 & 0.65 \\
\hline & Generation Xers (1965 and 1977) & 3.40 & 110 & 0.82 \\
\hline & Baby Boomers (1946 and 1964) & 3.45 & 64 & 0.73 \\
\hline & Overall OJMI & 3.53 & 289 & 0.74 \\
\hline
\end{tabular}


Table 5. Intercorrelations of the OJMI dimensions and reliabilities

\begin{tabular}{|c|c|c|c|c|c|c|c|c|c|}
\hline Factors & D1 & D2 & D3 & D4 & D5 & D6 & D7 & D8 & D9 \\
\hline $\begin{array}{l}\text { D1: } \\
\text { Distributive justice }\end{array}$ & 0.946 & & & & & & & & \\
\hline $\begin{array}{l}\text { D2: } \\
\text { Ethical leadership } \\
\text { and management }\end{array}$ & $.779 * *$ & 0.942 & & & & & & & \\
\hline $\begin{array}{l}\text { D3: } \\
\text { Service delivery } \\
\text { innovation }\end{array}$ & $.672 * *$ & $.791 * *$ & 0.909 & & & & & & \\
\hline $\begin{array}{l}\text { D4: } \\
\text { Strategic direction }\end{array}$ & $.633 * *$ & $.581 * *$ & $.576^{* *}$ & 0.884 & & & & & \\
\hline $\begin{array}{l}\text { D5: } \\
\text { Interactional justice }\end{array}$ & $.399 * *$ & $.434 * *$ & $.378 * *$ & $.596^{* *}$ & 0.862 & & & & \\
\hline $\begin{array}{l}\text { D6: } \\
\text { Informational justice }\end{array}$ & $.648 * *$ & $.720 * *$ & $.665^{* *}$ & $.631 * *$ & $.591 * *$ & 0.887 & & & \\
\hline $\begin{array}{l}\text { D7: } \\
\text { Procedural justice }\end{array}$ & $.801 * *$ & $.811 * *$ & $.697 * *$ & $.669 * *$ & $.499 * *$ & $.773 * *$ & 0.863 & & \\
\hline $\begin{array}{l}\text { D8: } \\
\text { Diversity management }\end{array}$ & $.633 * *$ & $.664 * *$ & $.600 * *$ & $.566^{* *}$ & $.589 * *$ & $.831 * *$ & $.705^{* *}$ & 0.815 & \\
\hline $\begin{array}{l}\text { D9: } \\
\text { Customer relations }\end{array}$ & $.629 * *$ & $.741 * *$ & $.643 * *$ & $.657 * *$ & $.640 * *$ & $.785^{* *}$ & $.679 * *$ & $.715^{* *}$ & 0.799 \\
\hline
\end{tabular}

The overall mean scores for all the three generational cohorts and the overall mean score of OJMI $(\mathrm{m}=$ 3.53) are also between the "agree" and "strongly agree" ratings on the Likert scale, indicating the employees seem to have satisfactory or positive perceptions of organizational justice.

The intercorrelations between the dimensions of organizational justice measured by the OJMI are presented in Table 5. All the dimensions of organizational justice correlate significantly with each other, namely, strategic direction, distributive, procedural, interactional, informational, service delivery innovation, customer relations, diversity management, and ethical leadership and management. Their correlations range from a minimum of $\mathrm{r}=0.399(\mathrm{p}=$ $<0.01)$ to a maximum of $r=0.831(p=<0.01)$.
The results of the ANOVA to determine significant differences in organizational justice perceptions mean scores for generational cohorts are depicted in Table 6. The overall results indicates that the three generational cohorts differ significantly in terms of the overall organizational justice mean score $(\mathrm{p} \leq 0.01)$. In addition, the cohorts differ significantly in the dimensions distributive $(p \leq 0.05)$, ethical leadership and management $(\mathrm{p} \leq 0.05)$, service delivery and innovation $(\mathrm{p} \leq 0.05)$, strategic direction $(\mathrm{p} \leq 0.05)$, interactional, informational $(\mathrm{p} \leq 0.05)$, and procedural justices $(\mathrm{p} \leq 0.000)$.

Table 7 also indicates that there are a significant difference between the mean scores of the Millennials, Generation Xers, and the Baby Boomers in several dimensions of organizational justice. 
Table 6. Analysis of variance (ANOVA)

\begin{tabular}{|c|c|c|c|c|c|c|}
\hline \multicolumn{2}{|c|}{ Dimensions } & \multirow{2}{*}{$\begin{array}{c}\begin{array}{c}\text { Sum } \\
\text { of Squares }\end{array} \\
8.139\end{array}$} & \multirow{2}{*}{$\frac{\mathbf{d f}}{2}$} & \multirow{2}{*}{$\begin{array}{c}\text { Mean } \\
\text { Square } \\
4.069\end{array}$} & \multirow{2}{*}{$\begin{array}{c}\mathbf{F} \\
4.347\end{array}$} & \multirow{2}{*}{$\begin{array}{c}\text { Sig. } \\
0.014^{*}\end{array}$} \\
\hline \multirow{3}{*}{ Distributive Justice } & between groups & & & & & \\
\hline & within groups & 267.723 & 286 & 0.936 & & \\
\hline & total & 275.861 & 288 & & & \\
\hline \multirow{3}{*}{$\begin{array}{l}\text { Ethical leadership and man- } \\
\text { agement }\end{array}$} & between groups & 6.832 & 2 & 3.416 & 3.988 & $0.020 *$ \\
\hline & within groups & 244.972 & 286 & 0.857 & & \\
\hline & total & 251.804 & 288 & & & \\
\hline \multirow{3}{*}{$\begin{array}{l}\text { Service delivery and inno- } \\
\text { vation }\end{array}$} & between groups & 8.954 & 2 & 4.477 & 4.576 & $0.011 *$ \\
\hline & within groups & 279.829 & 286 & 0.978 & & \\
\hline & total & 288.784 & 288 & & & \\
\hline \multirow{3}{*}{ Strategic direction justice } & between groups & 5.449 & 2 & 2.724 & 3.170 & $0.043 *$ \\
\hline & within groups & 245.755 & 286 & 0.859 & & \\
\hline & total & 251.204 & 288 & & & \\
\hline \multirow{3}{*}{ Interactional justice } & between groups & 3.969 & 2 & 1.985 & 2.703 & $0.069 *$ \\
\hline & within groups & 210.032 & 286 & 0.734 & & \\
\hline & total & 214.001 & 288 & & & \\
\hline \multirow{3}{*}{ Informational Justice } & between groups & 6.152 & 2 & 3.076 & 4.455 & $0.012 *$ \\
\hline & within groups & 197.480 & 286 & 0.690 & & \\
\hline & total & 203.632 & 288 & & & \\
\hline \multirow{3}{*}{ Procedural justice } & between groups & 14.520 & 2 & 7.260 & 8.870 & $0.000 * * *$ \\
\hline & within groups & 234.086 & 286 & 0.818 & & \\
\hline & total & 248.607 & 288 & & & \\
\hline \multirow{3}{*}{ Diversity justice } & between groups & 3.259 & 2 & 1.630 & 1.828 & 0.163 \\
\hline & within groups & 254.950 & 286 & 0.891 & & \\
\hline & total & 258.209 & 288 & & & \\
\hline \multirow{3}{*}{ Customer relations justice } & between groups & 1.461 & 2 & 0.731 & 1.075 & 0.343 \\
\hline & within groups & 194.303 & 286 & 0.679 & & \\
\hline & total & 195.764 & 288 & & & \\
\hline \multirow{2}{*}{ OJMI } & between groups & 6.046 & 2 & 3.023 & 5.572 & $0.004 * *$ \\
\hline & within groups & 155.163 & 286 & 0.543 & & \\
\hline
\end{tabular}


Table 7. Multiple comparison results

\begin{tabular}{|c|c|c|c|c|c|}
\hline $\begin{array}{c}\text { Organizational } \\
\text { justice }\end{array}$ & Generational & (J) Cohorts & $\begin{array}{l}\text { Mean Dif- } \\
\text { ference }\end{array}$ & $\begin{array}{c}\text { Standard } \\
\text { Error }\end{array}$ & $\begin{array}{r}\text { Signifi- } \\
\text { cance }\end{array}$ \\
\hline \multirow{2}{*}{ Distributive Justice } & \multirow{2}{*}{$\begin{array}{c}\text { born between } 1978 \\
\text { and } 2000\end{array}$} & $\begin{array}{c}\text { born between } 1965 \\
\text { and } 1977\end{array}$ & 0.281 & 0.129 & 0.089 \\
\hline & & $\begin{array}{c}\text { born between } 1946 \\
\text { and } 1964\end{array}$ & $0.409^{*}$ & 0.150 & 0.021 \\
\hline \multirow{2}{*}{$\begin{array}{l}\text { Ethical leadership } \\
\text { and management }\end{array}$} & \multirow{2}{*}{$\begin{array}{c}\text { born between } 1978 \\
\text { and } 2000\end{array}$} & $\begin{array}{c}\text { born between } 1965 \\
\text { and } 1977\end{array}$ & $0.320^{*}$ & 0.123 & 0.030 \\
\hline & & $\begin{array}{c}\text { born between } 1946 \\
\text { and } 1964\end{array}$ & 0.302 & 0.144 & 0.111 \\
\hline \multirow{2}{*}{$\begin{array}{l}\text { Service delivery } \\
\text { and innovation }\end{array}$} & \multirow{2}{*}{$\begin{array}{c}\text { born between } 1978 \\
\text { and } 2000\end{array}$} & $\begin{array}{c}\text { born between } 1965 \\
\text { and } 1977\end{array}$ & $0.394^{*}$ & 0.131 & 0.009 \\
\hline & & $\begin{array}{c}\text { born between } 1946 \\
\text { and } 1964\end{array}$ & 0.257 & 0.154 & 0.290 \\
\hline \multirow{2}{*}{$\begin{array}{l}\text { Strategic direction } \\
\text { justice }\end{array}$} & \multirow{2}{*}{$\begin{array}{c}\text { born between } 1978 \\
\text { and } 2000\end{array}$} & $\begin{array}{c}\text { born between } 1965 \\
\text { and } 1977\end{array}$ & $0.310^{*}$ & 0.123 & 0.038 \\
\hline & & $\begin{array}{c}\text { born between } 1946 \\
\text { and } 1964\end{array}$ & 0.129 & 0.144 & 1.000 \\
\hline \multirow{2}{*}{ Interactional justice } & \multirow{2}{*}{$\begin{array}{c}\text { born between } 1978 \\
\text { and } 2000\end{array}$} & $\begin{array}{c}\text { born between } 1965 \\
\text { and } 1977\end{array}$ & $0.262^{*}$ & 0.114 & 0.067 \\
\hline & & $\begin{array}{c}\text { born between } 1946 \\
\text { and } 1964\end{array}$ & 0.082 & 0.133 & 1.000 \\
\hline \multirow{2}{*}{ Informational justice } & \multirow{2}{*}{$\begin{array}{c}\text { born between } 1978 \\
\text { and } 2000\end{array}$} & $\begin{array}{c}\text { born between } 1965 \\
\text { and } 1977\end{array}$ & $0.302^{*}$ & 0.110 & 0.020 \\
\hline & & $\begin{array}{c}\text { born between } 1946 \\
\text { and } 1964\end{array}$ & 0.290 & 0.129 & 0.077 \\
\hline \multirow{2}{*}{ Procedural justice } & \multirow{2}{*}{$\begin{array}{c}\text { born between } 1978 \\
\text { and } 2000\end{array}$} & $\begin{array}{c}\text { born between } 1965 \\
\text { and } 1977\end{array}$ & $0.490^{*}$ & 0.120 & 0.000 \\
\hline & & $\begin{array}{c}\text { born between } 1946 \\
\text { and } 1964\end{array}$ & $0.380^{*}$ & 0.141 & 0.022 \\
\hline \multirow{2}{*}{ OJMI } & \multirow{2}{*}{$\begin{array}{c}\text { born between } 1978 \\
\text { and } 2000\end{array}$} & $\begin{array}{c}\text { born between } 1965 \\
\text { and } 1977\end{array}$ & $0.311^{*}$ & 0.098 & 0.005 \\
\hline & & $\begin{array}{c}\text { born between } 1946 \\
\text { and } 1964\end{array}$ & 0.260 & 0.114 & 0.072 \\
\hline
\end{tabular}

The following dimensions reflected differences among the three cohorts:

- First, the significant differences in the dimension distributive justice $\left(0.409^{*}\right)$ imply that Millennials scored high with the mean score of 3.51 when compared to the Baby Boomers with the mean score of 3.10 in this dimensions.

- Second, the significant differences in the dimension ethical leadership and management $\left(0.320^{*}\right)$ suggest that Millennials scored high with the mean score of 3.58 when compared to the Generation Xers with the mean score of 3.26 in this dimensions.

- Third, the significant differences in the dimension service delivery and innovation $\left(0.394^{*}\right)$ indicate that Millennials scored high with the mean score of 3.78 when compared to the Generation Xers with the mean score of 3.39 in this dimensions.

- Fourth, the significant differences in the dimension strategic direction justice $\left(0.310^{*}\right)$ reflect that 
Millennials scored high with the mean score of 3.76 when compared to the Generation Xers with the mean score of 3.45 in this dimensions.

- Fifth, the significant differences in the dimension interactional justice $\left(0.262^{*}\right)$ reflect that Millennials scored high with the mean score of 3.95 when compared to the Generation Xers with the mean score of 3.68 in this dimensions.

- Sixth, the significant differences in the dimension informational justice $\left(0.302^{*}\right)$ indicate that Millennials scored high with the mean score of 3.89 when compared to the Generation Xers with the mean score of 3.59 in this dimensions.

- Lastly, the significant differences in the dimension procedural justice between Millennials when compared with Generational Xers $\left(0.490^{*}\right)$ and Baby Boomers $\left(0.380^{*}\right)$ highlight that Millennials scored high with the mean score of 3.68 when compared to the Generation Xers with the mean score of 3.19 and Baby Boomers with the mean score of 3.30 in this dimensions.

These results indicate that there were no significant mean score differences between the three generational cohorts in the dimensions diversity and customer relations justice.

\section{$5 \quad$ Discussion and implications}

To date, there has been little research of generational difference on organizational justice within the context of a public service organization. An examination of the literature review indicates that organizational justice is positively associated to work performance, commitment, trust, retention, job satisfaction, and employee wellness. The aim of this study was to explore the role of organizational justice on employees' levels of work engagement.

The results indicate that both the OJMI have acceptable levels of internal consistency within the multicultural context of the South African public service organization. The correlational analysis shows that there is a positive correlation between organizational justice dimensions. The results of the mean as the descriptive statistic indicates that employees of the public service organization seem to have positive perception of all organizational jus- tice dimensions, namely, interactional justice, customer relations, informational, strategic direction, service delivery and innovation, diversity management, procedural, ethical leadership and management, and distributive justice.

When assessing the differences between the generational cohorts, post hoc comparisons revealed a consistent trend that Millennials were significantly higher in their mean scores than both Generation Xers and Baby Boomers on all dimensions of organizational justice. This indicates that Millennials generation seems to have a more positive perception that their organization is just and fair in its practices. The mean differences between Baby Boomers and the two other cohorts, however, may reflect agerelated changes to some extent [24]. Although Generation Xers mean scores were higher than Baby boomers in five dimensions (distributive, ethical leadership and management, service delivery innovation, interactional, and customer relations justice), there were no significant differences between the two generational cohorts. This pattern appears to suggest that Millennials demonstrated the highest positive perception of organizational justice across the three cohorts. Literature indicates that these generational differences may be partially attributable to age or the career stages of the three generations [20]. Millennials with respect to the age at which they completed the OJMI were significantly younger than the participants representing Generation Xers and the Baby Boomer cohorts [24, 20]. This implies that younger employees are inclined to have high positive perceptions on organizational justice. These positive perceptions by young employees may also be attributed to the human resource practices of the knowledge economy organization, which endorses high performance as criteria for promotions and remuneration increases rather than seniority or years of service in an organization. In addition, the use of technology in today's organizations may be another factor that may be attributed to the positive perceptions.

This study has several practical implications for employees and organizations. First, these finding are noteworthy because it gives organizations inexpensive means of enhancing their employees' positive perception on organizational justice. 
Second, practitioners and managers in public service organizations need to identify generational differences that influence organizational justice perceptions. Lastly, organizations are able to develop relevant interventions to ensure positive perceptions of organizational justice when managing multigenerational groups; ultimately, this may help to create a more engaged workforce in the public service organization.

\section{Conclusions, limitation, and recommenda- tions for future research}

This study aimed to provide insight into the generational differences of employees in a public service organization regarding their organizational justice perceptions. The purpose of this study was achieved because the results explain the generational differences between the Millennials, Generation Xers, and Baby Boomers cohorts' perception of organizational justice. Young generation in this organization that are Millennials seems to have a high positive perception of their organization in terms of its practices and processes of creating a fair and just work environment.

Limitation of this study is that it cannot be generalized to other organizational context other than the one from which data were gathered. Participants of this study sample are from a single organization in a specific public service organization. This approach reinforces the internal validity of this study; but it also limits its external validity. Conducting a cross-sectional study rather than a longitudinal design has challenges and limitations in establishing a causal relationship between the variables being studies.

In terms of future research, it is that a replica of this study be conducted in a variety of organizational context in order to allow the results to be extrapolated to other context. A longitudinal studies would also assist in establishing a causal relationship between organizational justice and generational cohorts.

\section{$7 \quad$ References}

[1] Bakker A.B., Demerouti E. (2007) - The job demands-resources model: State of the art. Journal of Managerial Psychology, 22, pp. 309-328.

[2] Bowen D.E., Gilliland S.W., Folger R. (1999) - HRM and service justice: How being just with employees spills over to customers. Organizational Dynamics, 27, pp. 7-23.

[3] Colquitt J.A. (2001) - On the dimensionality of organizational justice: a construct validation of a measure. Journal of Applied Psychology, 86, pp. 386-400.

[4] Cropanzano R., Rupp D.E., Mohler C.J., Schminke M. (2001) - Three roads to organizational justice. Research in Personnel and Human Resources Management, 20, pp. 1113.

[5] Cropanzano R, Bowen D.E., Gilliland W. (2007) - The management of organizational justice. Academy of Management Perspectives, November, pp. 34-47.

[6] Cropanzano R., Prehar C.A., Chen P.Y. (2002) - Using social exchange theory to distinguish procedural from interactional justice. Group and Organizational Management, 27, pp. 324351.

[7] Dorasamy N. (2010) - Enhancing an ethical culture through purpose - directed leadership for improved public service delivery: A case for South Africa. African Journal of Business Management, 4 (1), pp. 56-64.

[8] Esterhuizen W. (2008) - Organisational justice and employee responses to employment equity. Unpublished Masters Dissertation. University of South Africa.

[9] Esterhuizen W., Martins N. (2008) - Organisational justice and employee responses to employment equity. South African Journal of Labour Relations, 32 (2), pp. 65-85.

[10] Gaudet M.C., Tremblay M., Doucet O. (2014) - Exploring the black box of the contingent reward leadership-performance relationship: The role of the perceived justice and emotion- 
al exhaustion. European Journal of Work and Organizational Psychology, 23 (6), pp. 897914.

[11] Goldstein S.M., Johnston R., Duffy J., Rao J. (2002) - The service concept: the missing link in service design research? Journal of Operations Management, 20, pp. 121-134.

[12] Greenberg J. (1987) - Reactions to procedural injustice in payment distributions: Do the means justify the ends? Journal of Applied Psychology, 72, pp. 55-61.

[13] Hill R.P. (2002) - Managing across generations in the 21st century: important lessons from the ivory trenches. Journal of Management Inquiry 11 (1), pp. 60-66.

[14] Kahn J. (2006) - Factor analysis in counselling psychology research, training, and practice: principles, advances and applications. The Counselling Psychologist, pp. 34-684.

[15] Karp H., Fuller C., Sirias D. (2002) - Bridging the Boomer Xer Gap. Palo Alto: DaviesBlack.

[16] King S.F., Burgess T.F. (2008) - Understanding success and failure in customer relationship management. Industrial Marketing Management, 37, pp. 421-431.

[17] Kupperschmidt B.R. (2000) - Multigeneration employees: strategies for effective management. Health Care Manager, 19 (1), pp. 65-76.

[18] Macky K., Gardner D. Forsyth S. (2008) Generational differences at work: introduction and overview. Journal of Managerial Psychology, 23 (8), pp. 857-861.

[19] Magoshi E., Chang E. (2009) - Diversity management and the effects on employees' organizational commitment: Evidence from Japan and Korea. Journal of World Business, 44, pp. 31-40.

[20] Meriac J.P., Woehr D.J., Banister C. (2010) Generational Differences in Work Ethic: An Examination of Measurement Equivalence Across Three Cohorts. Journal of Business Psychology, 25, pp. 315-324.
[21] Moorman R.H. (1991) - Relationship between organizational justice and organizational citizenship behaviors: Do fairness perceptions influence employee citizenship? Journal of Applied Psychology, 76, pp. 845-855.

[22] Park J., Gursoy D. (2012) - Generation effects on work engagement among U.S. hotel employees. International Journal of Hospitality Management, 31, pp. 1195-1202.

[23] Pilvinyte M. (2013) - Perceptions of organisational justice, restorative organisational justice, and their relatedness to perceptions of organisational attractiveness. Unpublished Masters Dissertation. University of Witwatersrand.

[24] Pogson C., Cober A., Doverspike D., Rogers J. (2003) - Differences in self-reported work ethic across three career stages. Journal of Vocational Behavior, 62, pp. 189-201.

[25] Raines C. (2002) - Managing Millennials. Retrieved February 24, 2015, from Generations at Work Web Site:

www.generationsatwork.com/articles/millenial s.htm.

[26] Shibaoka M., Takade M., Watanabe M., Kojima R., Kakinuma M., Tanaka K., Kawakami N. (2010) - The development and validation of the Japanese version of the organisational justice scale. Industrial Health, 48, pp. 66 - 73.

[27] Smola K.W., Sutton C.D. (2002) - Generational differences: revisiting generational work values for the new millennium. Journal of Organizational Behavior, 23 (4), pp. 363382.

[28] SPSS Inc. (2006) - SPSS version 14.0 for the Microsoft Windows platform. Chicago: SPSS Inc.

[29] TerreBlanche M., Durrheim K., Painter D. (2006) - Research in practice: applied methods for the social sciences. Cape Town: University of Cape Town Press. 
[30] Twenge J.M. (2010) - A review of the empirical evidence on generational differences in work attitudes. Journal of Business and Psychology, 25 (2), pp. 201-210.

[31] Van der Bank L., Engelbrecht A., Stumpher J. (2010) - Perceived fairness of disciplinary procedures in the public sector: an exploratory study. South African Journal of Human Resource Management, 6(2), pp. 1-8.
[32] Welman C., Kruger F., Mitchell B. (2009) Research methodology. Cape Town: Oxford University Press.

[33] Werner A. (2005) - Organizational behaviour: A contemporary South African perspective. Pretoria: Van Schaik.

[34] Zemke R., Raines C., Filipczak B. (2000) Generations at work. New York: Amacon. 